\title{
Ambiguitas Pemaknaan Pesan Sebagai Komodifikasi dalam Personality Peformance Multikultural Pada Sosok Soimah
}

\author{
Kheyene Molekandella Boer
}

Universitas Mercu Buana Yogyakarta

\begin{abstract}
The intense competition between private television in Indonesia force the television workers to rise their effort in order to still competitive. The implication is private television should make a program that could give high ratings. It means, television workers treat their programme as a commodification. One example of commodification by Indonesian private television is the presence of Soimah. Soimah is being performed as Javanese traditional woman. But in her performance, Soimah act as Javanese woman that have oral competence -the things that contrary with the Javanese culture. In Javanese culture, woman should polite, kind, and elegant.

This article assumed media representation could create cultural ambiguity message and shared meaning process that could be misinterpret by the audience. The image of Javanese woman could distort. Here, commodification victimize the cultural element. This article discuss about representation in Soimah's personality performance in television.
\end{abstract}

Keywords: cultural commodification, message ambiguity, personality performance

\begin{abstract}
Abstrak
Menjamurnya televisi swasta di Indonesia, membuat insan-insan televisi kerap memutar otak agar televisi mereka dapat bertahan ditengah ketatnya persaingan industri pertelevisian. Fakta inilah yang menuntut televisi swasta untuk mencari kehidupan dengan menghambakan rating dalam setiap program acara mereka. Segala bentuk komodifikasi yang dilakukan oleh insan pertelevisian, salah satunya adalah fenomena hadirnya sosok Soimah yang ditampilkan sebagai perempuan Jawa. Seharusnya Soimah diberikan tempat yang tepat untuk menjadi pelestari budaya Jawa dengan tetap mempertahankan unsur keanggunan, kesantunan, kesopanan seorang wanita Jawa pada umumnya bukan sebaliknya. Soimah justru ditampilkan sebagai sosok wanita Jawa yang memiliki kecakapan lisan yang sangat bertolak belakang dengan budaya Jawa yang sesungguhnya.

Representasi dari media diasumsikan dapat menjadi ambiguitas pesan kultural serta proses pertukaran makna yang pada akhirnya salah dipersepsi penonton televisi. Citra wanita Jawa kemungkinan besar akan tergeser menjadi wanita yang kasar walaupun ia pintar menyindenkan lagu Jawa. Komodifikasi di sini terlihat mengorbankan banyak sekali unsur budaya demi profit semata. Penelitian ini tertarik membahas representasi pada personality performance Soimah di televisi.
\end{abstract}

Kata kunci : komodifikasi budaya, ambiguitas pesan, personality performance 


\section{Pendahuluan}

Menjamurnya televisi swasta di Indonesia, membuat insan-insan televisi kerap memutar otak agar televisi mereka dapat bertahan ditengah ketatnya persaingan industri pertelevisian. Fakta inilah yang menuntut televisi swasta untuk mencari kehidupan dengan menghambakan rating dalam setiap program acara mereka, sehingga telah menjadi rahasia umum bahwa industri media adalah salah satu bisnis yang cukup menjanjikan. Segala bentuk komodifikasi yang dilakukan oleh insan pertelevisian, salah satunya adalah fenomena hadirnya sosok Soimah. Perempuan pecinta budaya Jawa ini, terkenal dengan keunikannya yang berani tampil dilayar kaca dengan selalu menggunakan kebaya lengkap dengan sanggulnya. Sayangnya, media dengan sengaja menempatkan Soimah dengan segala keunikannya ditempat yang salah. Seharusnya Soimah diberikan tempat yang tepat untuk menjadi pelestari budaya Jawa dengan tetap mempertahankan unsur keanggunan, kesantunan, kesopanan seorang wanita Jawa pada umumnya bukan sebaliknya. Soimah ditampilkan sebagai sosok wanita Jawa yang memiliki kecakapan lisan yang sangat bertolak belakang dengan budaya Jawa yang sesungguhnya. Representasi dari media diasumsikan dapat menjadi ambiguitas pesan kultural serta proses pertukaran makna yang pada akhirnya salah dipersepsi penonton televisi. Citra wanita Jawa kemungkinan besar akan tergeser menjadi wanita yang kasar walaupun ia pintar menyindenkan lagu Jawa. Komodifikasi disini terlihat mengorbankan banyak sekali unsur budaya demi profit semata. Penelitian ini tertarik membahas representasi pada personality performance Soimah di televisi

Media sebagai referensi dominan khalayak untuk memperoleh beragam informasi. Media memiliki kuasa penuh untuk merancang semua pesan-pesan sesuai keinginan mereka tanpa ada campur tangan dari pemerintah. Di satu sisi hal ini dinilai sebagai angin segar pasca pemerintahan orde lama, tetapi disisi lain fenomena ini kian dinilai bablas karena media memiliki pengaruh yang kuat sebagai alat propaganda yang cukup efektif. Media mampu mengasah semua jenis informasi agar memiliki "value" yang bisa dijual kepada khalayak dengan harga yang tinggi. Budaya-pun tak luput dari ekspose media yaitu dengan merepackaging ulang sebuah simbol-simbol kebudayaan tanah air dengan tujuan baik, yaitu mempertahankan budaya tradisional Indonesia di mata masyarakat Indonesia. Akan tetapi pada akhirnya media lepas kendali/lost control dan tidak berhati-hati dalam menghadirkan kemasan budaya dalam bentuk hiburan modern yaitu acara acara televisi. Media seolah terjebak dalam dua tujuan yang bertolak belakang, dimana mereka ingin terus mengeksiskan budaya Indonesia secara modern dan tujuan lainnya mereka tak memperhatikan 
interpretasi masyarakat Indonesia yang mungkin saja dalam menangkap pesan budaya tersebut tak sejalan atau terpeleset dari apa yang diinginkan oleh pihak media. Beberapa tahun terakhir ini, bertebaran beragam tayangan di berbagai stasiun televisi swasta yang memuat unsur kebudayaan lokal sebagai nilai plus untuk ditawarkan kepada khalayak. Berikut hasil pengamatan penulis tentang programprogram acara yang turut menyertakan unsur budaya dibeberapa televisi swasta Indonesia :

Tabel 1.1 :

Gambar Program Acara Bernuansa Kultural Di Televisi

\begin{tabular}{lll}
\hline \multicolumn{1}{c}{ Stasiun TV } & \multicolumn{1}{c}{ Program Acara } & Deskripsi Unsur Budaya \\
\hline TRANS TV & Keluarga MINUS & Papua \\
TRANS TV & Bukan Empat Mata & Jawa \\
TRANS TV & Show Imah & Jawa \\
TRANS 7 & Opera Van Java (OVJ) & Jawa \\
TRANS 7 & Hidup Itu Indah & Jawa \\
TRANSTV, & Bajaj Bajuri & Jawa, Padang, Betawi \\
ANTEVE, SCTV & & \\
\hline
\end{tabular}

Sumber : Pengamatan peneliti ditahun 2011-2012

Acara acara di atas memiliki konsep yang berbeda-beda, mulai dari sinetron komedi yang diusung oleh "Bajaj Bajuri" dan "Keluarga Minus", konsep talk show dalam acara "Bukan Empat Mata" dan "Show Imah", konsep reality show dalam acara "Hidup Itu Indah", dan konsep acara drama komedi dalam acara "Opera Van Java”. Tulisan ini ingin mengidentifikasi bukan pada program acara yaitu lebih kepada sosok pribadi atau identitas yang ditampilkan oleh Soimah, dengan alasan kehadiran Soimah adalah sebuah fenomena baru dalam industri televisi Indonesia, ia mampu membuat beberapa stasiun TV Indonesia berebut untuk menampilkan sosoknya yang identik dengan kebudayaan Jawa yang dianggap melawan arus tersebut.

Acara bertemakan "Show Imah" berada dalam naungan Trans $T V$ dengan jam tayang mulai dari hari Senin hingga Jumat, pukul 16.30 WIB. Soimah Pancawati adalah nama asli Soimah berperan sebagai host dan tampil lengkap menggunakan atribut jawa yaitu sanggul, make up tebal dan balutan kebaya sebagai ciri khas dari kebudayaan Jawa. Hal yang menjadikan unik adalah tingkah laku Soimah dianggap bertolak belakang dengan atribut yang ia kenakan dapat dilihat dari gaya berbicara seperti intonasi, pemilihan kata-kata, kekerasan suara, ekpresi wajah dan gesture, lebih 
terlihat hyperaktif dengan beragam tingkah pola yang ia keluarkan, meskipun begitu ia mahir menembangkan lagu Jawa dengan indah.

Wanita asal kota Pati, Jawa Tengah ini mampu mengundang tawa pemirsa melalui ekspresi wajah dan tingkah laku. Gaya bicaranya yang terkenal 'ceplasceplos' dengan mengeluarkan kata yang malah menjadi trend di kalangan anak muda yaitu "Masalah buat Loe?". Dalam acara talk show, terkadang ia menanggalkan segala atribut Jawa seperti kebaya, konde dan make up tebalnya. Ia memilih untuk tampil dengan rambut yang dibiarkan terurai bergelombang, blazer, rok atau celana yang simple, di mana atribut yang dikenakan mencirikan sebagai sosok wanita yang lekat dengan kehiduan dinamis, aktif, simple, modern dan pintar. Di luar dari penampilan modern diacara tersebut Soimah tetap mempertahankan identitas buayanya dari logat, celetukan dan sekali kali memperlihatkan kemampuan nembang Jawa-nya sekalipun dia sedang tidak memakai kebaya. Karena ia tahu benar itulah nilai jual yang ada didalam dirinya. Dominasi penampilan Soimah di media agaknya perlu disoroti, karena dengan intensnya media menampilkan sosok Soimah maka ditakutkan akan terjadi pergeseran makna yang ditangkap khalayak tentang pemaknaan terhadap perempuan Jawa. Akankah sosok seperti Soimah memiliki pengaruh yang besar untuk memudarkan nilai-nilai kesakralan pada perempuan Jawa yang sesungguhnya?

\section{Membingkai Kebudayaan dalam Perspektif Media}

Budaya adalah unsur yang penuh dengan kesakralan dan rasa penghormatan tinggi bagi siapapun yang memahaminya dengan benar. Namun dengan kreativitas insan pertelevisian Indonesia, kini budaya dapat dengan mudah di komodifikasi. Jawa adalah budaya yang berciri khas mengutamakan kesopanan, kesantunan dan kesungkanan. Dari latar belakang inilah akhirnya budaya Jawa dicoba untuk ditampilkan dengan konsep melawan arus pemikiran zaman dulu. Dimana, kini anak muda yang menganggap Jawa adalah budaya yang ketinggalan zaman. Tetapi dengan hadirnya sosok Soimah dinilai sebagai bentuk keekspresifan perempuan dijaman yang serba bebas ini.

Kehadiran Shoimah membuat pemirsa televisi membuka pemikiran lebar tentang pendefinisian budaya Jawa. Pesan yang disampaikan media tidak secara ketat disaring agar bisa diterima sesuai dengan apa yang diharapkan media bukannya menimbulkan ambiguitas bagi khalayak dalam menginterpretasikannya. Dahulu citra Jawa dari segi tradisi, sikap dan karakter orang Jawa membutuhkan waktu yang lama dalam mengemasnya hingga dikenal ke pelosok dunia. Namun dengan tampilnya sosok Soimah, citra 
yang dibuat puluhan tahun tersebut terlunturkan seketika menjadi citra yang cenderung negatif (bukan ekpresi atau simbol kebebasan bagi masyarakat Jawa)..

Budaya berasal dari bahasa sansekerta yaitu buddhayah, yang merupakan bentuk jamak dari buddhi (budi dan akal) artinya hal-hal yang berkaitan dengan budi dan akal manusia. Kebudayaan (Kroeber \& Kluckoln, 1952:181) :

Budaya adalah fenomena yang terdiri dari pola-pola, baik yang eksplisit maupun yang implisit, tentang dan untuk perilaku yang diperoleh dan disebarluaskan melalui simbol-simbol, membentuk prestasi khas kelompok-kelompok manusia, termasuk perwujudanya dalam bentuk berbagai artefak; inti kebudayaan yang paling esensial terdiri dari ide-ide tradisional (yaitu ide-ide yang diderivasi dan diseleksi secara historis) dan terutama nilai-nilai yang dinisabkan kepadanya; sistem-sistem budaya, disatu sistem dapat dianggap sebagai produk tindakan dan disisi lain sebagai elemen-elemen yang mengondisikan tindakan selanjutnya

Artinya kebudayaan merupakan simbol-simbol untuk membedakan kelompok-kelompok sosial lainnya baik secara eksplisit dan implisit. Soimah mencoba menyampaikan Jawa dengan dua cara tersebut yaitu secara eksplisit melalui atribut yang ia kenakan dan secara implisit melalui tingkah laku yang ia keluarkan. Kini peran media berada dalam triangulasi negara, pasar dan civil society. Media-lah yang menghubungan ketiga komponen tersebut, pada masa reformasi hubungan triangulasi lebih didominasi oleh pasar, sedangkan dahulu didominasi oleh negara. Seharusnya, media menjadi penghubung ketiga komponen tersebut, dan tidak boleh berada atau berpihak pada satu komponen saja. Kini kebudayaan sudah bukan sesuatu yang sakral lagi, karena ternyata dengan media kesakralan itu dapat berubah menjadi budaya yang dapat dimodifikasi sesuai dengan keinginan elit penguasa. Media menjalankan banyak fungsi selain sebagai alat untuk memberikan informasi kepada masyarakat, media kerap menjalankan fungsi sebagai penganut kepentingan propaganda politik juga ekonomi.

\section{Jawa Dalam Balutan Komedi}

Beberapa tahun terakhir muncul beberapa nama komedia yang kian laris menghiasi wajah pertelevisian Indonesia. Demam acara komedi nampaknya mampu menarik perhatian khalayak yang mungkin tengah jenuh dengan pergulatan kondisi politik Indonesia saat ini. Komedi hadir menjadi angin segara bagi khalayak sebagai hiburan yang ringan. Maraknya program ber-genre komedi tak lepas dari aktor yang diistilahkan dengan sebutan pelawak atau komedia. Pelawak/ komedian adalah profesi yang sejajar dengan penyanyi, musisi, pemain sinetron, sutradara dan lain lain. 
Komedi adalah salah satu unsur krusial yang tidak boleh dipandang sebelah mata. Di mana komedi merupakan salah satu cara efektif untuk mencairkan suasana dan disukai oleh banyak orang. Tujuan dari adanya tayangan komedi adalah untuk merilekskan saraf yang tegang. Komedi biasanya disajikan sebagai packaging dari sebuah program acara, karena khalayak lebih menyukai hal yang lucu daripada yang serius. Di pertelevisian Indonesia sendiri banyak acara yang ber-genre komedi laris manis dan hilir mudik tiap jam-nya. Perubahan format, tata cara lawakan (komedi)-pun berubah seiring berkembangnya zaman. Komedi terbentuk dan tumbuh sesuai kebutuhan dan situasi sosial lingkungan yang terjadi. Terdapat sisi positif dan negatif pada fenomena yang terjadi dalam acara komedi di tanah air. Pertama, dengan komedi kita bisa melihat bagaimana situasi sosial, budaya, politik yang terjadi. Karena diatas panggung muncul segala kritik dalam bentuk lelucon. Negatifnya, Kini komedi didominasi oleh unsur kekerasan verbal dan non verbal (lisan) sehingga muncullah ambiguitas pemaknaan dari interaksi komunikasi aktor komedi tersebut yang ditangkap oleh khalayak.

Pelawak atau komedian adalah orang yang menghibur penonton, terutama dalam membuat mereka tertawa. Cara yang paling umum adalah dengan mengucapkan lelucon orang lain atau diri sendiri, tingkah laku yang dibuat- buat. Di Indonesia bentuk lawak yang terkenal dan melegenda adalah grup Srimulat, Warkop DKI dan Patrio. Namun semakin berkembangnya industri televisi kini banyak lawakan yang terdiri dari satu orang saja alias independent. Mereka melawak bukan merujuk pada sebuah cerita yang dikonsep terlebih dahulu, melainkan dengan cara spontanitas saja. Menurut Mamiek Prakoso yang juga seorang komedian, menurutnya seorang pelawak adalah sebagai penghibur bukan penghancur artinya, lawakan yang dibawanya haruslah sesuatu yang dapat menghibur keseluruhan pihak dan tidak menyakiti sebagian pihak.("Mamik Prakoso: Pelawak Sebagai Penghibur Bukan Penghancur", Kompasiana.com, 30 Juni 2012).

Dalam acara yang di usung Metro TV dengan tema "Seni Pelawak Tunggal" menjelaskan seorang pelawak dituntut untuk paham apa tema yang sedang diangkatnya atau materi yang dibawakannya serta memberikan solusi yang digambarkan dari lawakan tersebut. Seorang pelawak harus memiliki karakter sebagai ciri khasnya agar semakin mudah mengkonsep lawakan tersebut. Melontarkan lawakan yang lucu dan membuat orang tertawa namun di pihak lain ada orang yang merasa tersinggung dan tak lucu melihat lawakan tersebut maka tujuan lawakan itu telah terpeleset bukan sebagai hiburan. Kini profesi lawakan telah mengalami pergeseran, lawakan berkualitas kini amat susah 
didapatkan, ini terlihat dari pelawak pelawak tunggal yang menyajikan lawakannya dengan tidak sehat alias banyak lawakan yang tidak berkonsep atau banyak pula yang menyelipkan unsur kekerasan.

Pelawak tak mungkin terkenal tanpa eksplorasi media. Media mampu merubah segalanya karena bersifat powerful. Namun yang disayangkan media bergerak berdasarkan profit atau keuntungan semata, pihak media tidak pernah memberikan filter apa yang layak dan tak layak dikonsumsi secara berlebihan oleh pemirsanya. Lawakan yang cerdas adalah lawakan yang tidak mendiskriminasi etnis-etnis, ras atau suku.

Seiring berkembangnya zaman peran media kini menjadi bisnis yang menjanjikan. Industri media dapat dijadikan alat propaganda serta untuk mengumpulkan pundi-pundi uang. Terutama dengan merebaknya televisi swasta yang tentunya tidak mendapatkan subsidi dari pemerintah, sehingga mereka harus memutar otak untuk dapat bertahan hidup dan terus eksis dalam dunia pertelevisian, yaitu dengan membuat program program yang menarik agar publik menyukai apa yang televisi tersebut sajikan, sehingga keuntungan (profit) dapat mereka tuai. Dalam Undang Undang Penyiaran nomor 32 tahun 2002, menjelaskan asumsi dasar kemampuan yang harus dimiliki oleh media penyiaran televisi swasta : (1) Fungsi ekonomi : kemampuan untuk menghidupi dirinya sendiri, (2) Fungsi sosial : kemampuan untuk memperjuangkan kepentingan masyarakat. Kedua asumsi tersebut jika dipaparkan lebih lanjut, didalamnya terjadi kepentingan ekonomi dan isi pesan media , teori ekonomi politik media erat hubungannya dengan sistem politik. Jika dahulu media dipandang hanya sebagai penyaji teks biasa, namun dibalik itu semua kita bisa melihat 'apa yang sebenarnya terjadi', kini media sebagai pergulatan kepentingan pemilik dan sebuah ideologi karena permasalahan kepemilikan (ekonomi) dan kekuasaan (politik).

Media telah melakukan kekerasan simbolik terhadap suku Jawa, salah satunya melalui sosok Soimah. Teori representasi (Theories of Representation) dengan pendekatan konstruksionis (constructionist approach) milik Stuart Hall (1997), menjelaskan representasi adalah bagian terpenting dari proses dimana arti (meaning) diproduksi dan dipertukarkan antara anggota kelompok dalam sebuah kebudayaan (culture). Dalam kasus ini televisi telah melakukan pross representasi atas objek yang ditampilkan didalam acara atau sosok dengan menggunakan bahasa. Sosok soimh menggunakan unsur-unsur Jawa sebagai penyampaian pesan kepada pemirsa melalui atribut yang menempel ditubuh perempuan asal kota Pati tersebut. Bahasa menurut Ferdinand de Saussure (1857-1913) menjelaskan bahwa ciri pembeda yang paling menonjol karena 
dengan bahasa setiap kelompok sosial merasa dirinya sebagai kesatuan yang berbeda dengan kelompok lainnya. Representasi pemirsa merupakan bentuk pertanggungjawaban media yang harus dijalankan, karena menyangkut moralitas, citra, pandangan budaya Jawa yang dikomodifikasi oleh media tersebut.

Menurut pakar media Prof.Mark Hobart dari School of Oriental and African Studies dalam pemaparan dihadapan Perhimpunan Pelajar Indonesia (PPI) di London mengatakan bahwa dirasa perlu untuk mengubah wajah pertelevisian Indonesia. Tidak dapat dipungkiri masyarakat lebih peduli kepada tayangan televisi dibandingkan agenda pemerintah ("Televisi Pengaruhi Wajah Media, Meski Pemirsa Kerap Tak Tahu Realitas Asli Peristiwa”. Republika.co.id, 27 November 2011).

Televisi banyak sekali memiliki dampak dan fungsi untuk mempengaruhi masyarakat yang defensif menjaadi agresif, memberikan kontruksi pengetahuan yang positif, pertukaran gagasan dan nilai kontrol sosial publik, namun dapat juga memberikan nilai nilaiyag menjatuhkan aspek etika, moralitas, keseimbangan diri melalui sesuatu yang sifatnya komersial (komodifikasi).

Tayangan yang laris manis adalah tayangan yang mampu mengaduk aduk emosionalitas, seperti salah satunya adalah komedi. Televisi dengan sengaja memperlihatkan kevulgaran berkomedi dan mengesampaingkan nilai nilai moralitas, nilai budaya Timur demi kepentingan pasar dan industri. Menurut Habermas (1991) kesalahan terbesar media elektronika adalah ketika nilai-nilai pedagogis, pencerdasan diabaikan dan tidak memberikan diseminasi pengaruh yang membentuk nilai tambah bagi pemikiran dan pembangunan karakter masyarakat lewat konten konten yang berkualitas.

Personality performance adalah tampilan luar yang sengaja dikemas oleh individu untuk menampilkan keunikan dan citra diri yang ingin dibangun dimata masyarakat. Soimah yang baru-baru ini mondar mandir dalam acara televisi. Perempuan asal Jogjakarta ini pandai menyindenkan berbagai jenis lagu dengan suaranya yang merdu, terlebih lagi tampilannya yang memang selalu dibalut dengan pakaian kebaya. Sangat terlihat anggun, karena jarang sekali ada seorang artis yang berani tampil menggunakan pakaian tradisional. Mengingat kini budaya kita kurang begitu disorot dan tidak akan laku jika dijual dinegara sendiri,dikarenakan pola hidup kita secara tak langsung banyak mengadopsi dari budaya barat.

\section{Komodifikasi Jawa Pada Sosok Soimah}

Nama lengkapnya adalah Soimah Pancawati, seorang sinden asli Jogjakarta 
dan penyanyi campur sari ini lahir pada tangga 29 September 1980. Memang baru dikenal publik belakangan ini saja. Lantaran tampilannya yang nyentrik dibanding artis lainnya. Dikenal dengan keahliannya menyanyikan lagu campur sari atau sinden, Soimah acap kali diminta untuk mengisi acara acara hiburan, seperti dahsyat sebagai MC dengan modal kegokilaanya tersebut. Namun memang sangat disayangkan apa yang digunakannya dengan tingkah lakunya jauh berbeda, misalnya walaupun dia menggunakan baju tradisonal. Attitudenya sangat bertolak belakang, seperti dengan gaya jalannya yang suka “ngangkang”, gaya tertawanya yang lepas, berbicara suka berteriak dan membentak. Walaupun begitu soimah dipercaya untuk memegang sebuah acara Talkshow sendiri yang bernama "Show Imah".

Media massa sebagai agent of destroyer memang kerap memicu munculnya masalah- masalah sosial di masyarakat, karema televisi adalah media hiburan yang murah sehingga dirasa merupakan sarana yang paling tepat untuk memproleh hiburan. Permasalahan sosial yang kerap dimunculkan dimedia massa adalah kekerasan. Jika hal ini terus menerus dikonsumsi masyarakat secara berkelanjutan maka akan berdampai negatif bagi masyarakat.

Dalam acara Show Imah, ia berperan sebagai moderator atau pembawa acara sekaligus tuan rumah. Format talkshow yang dibawakan dengan ringan dan topik yang hangat. Bintang tamunya pun setara dengan yang memiliki latar belakang artis saja. Pertanyaan yang dilempar juga seputar privasi bintang tamu. Karena dalam format ini yang dijual bukanlah konteks, melainkan pembawaan Soimah selama acara berlangsung. Apakah ia mampu memberikan hiburan yang disukai pemirsa dengan aksen yang ia miliki. Selama acara berlangsung soimah juga tidak melulu menggunakan kebaya, ia kerap kali muncul berbusana modis dengan style masa kini. Dalam berkomunikasi ia tetap menggunakan logat Jawa, karena itu adalah salah satu ciri khasnya.

Didalam sosok Soimah banyak hal yang unik dan mampu menjadi nilai jual yang laris manis dipasar industri media :

1) Hiperaktif

Meskipun kostum yang kerap kali ia gunakan yaitu kebaya Jawa yang identik dengan wanita Jawa yang terkenal halus, baik, ramah, sopan dan santun. Namun apa jadinya jika kebaya tersebut melekat didalam diri Soimah. Akankah citra negatif akan wanita Jawa akan bergeser menjadi wanita yang hiperaktif, pecicilan. Terutama dengan logat Jawanya yang begitu kental yang menjadikan ciri khas Soimah dengan yang lainnya. Walaupun memiliki logat Jawa yang kental,ia sering didaulat untuk menjadi host tamu dalam beberapa acara televisi dan ia tetap 
mempertahankan akses logat Jawanya. Pantas saja karena karir Soimah dalam dunia seni dimulai sejak ia bersekolah di sekolah Menengah Karawitan Jogjakarta tahun 1995 dan ia juga sempat bersekolah di Institut Kesenian Indonesia di Yogyakarta.

\section{2) Historis Soimah}

Rumah orangtuanya di Pati Jawa Tengah sering dijadikan tempat singgah pemain ketoprak tobong. Karena melihat bakat Soimah, bibinya mengajak Soimah untuk pindah ke Jogja dalam rangka mengembangkan bakatnya. Sampai pada akhirnya ia berlatih tari di padepokan Bagong, dari sinilah ia mulai sering diajak manggung menjadi sinden. Karena rasa keingintahuannya yang besar ia tak ingin mempelajari seni diluar wayang, lalu ia bergabung masuk kedalam kelompok musik Acapella Mataraman. Ia juga belajar akting dan sempat menjadi pembawa acara "klinng klinong Campur Sari" disalah satu stasiun televisi lokal.

3) Hip Hop Jawa

Dibalik identitasnya sebagai seorang sinden, Soimah ternyata juga bergabung dengan Jogja Hip Hop Fondation, ia juga mengadakan tour bersama Hip Hop Foundation ke Asia Society, New York, Amerika Serikat untuk mempopulerkan bahasa Jawa melalui hip hop, ia pun disambut luar biasa oleh hip hopper Bronx. Soimah tercatat aktif mengkampanyekan kesenian dan budaya Indonesia di mata dunia.

Kondisi pertelevisian kita benar benar telah memasuki era dimana produk produknya ditentukan oleh the invisible hand mekanisme pasar yang bertumpu pada kaidah permintaan penawaran, logika sirkuit modal dan rasionalitas maksimalisasi produksi dan konsumsi (Sudibyo,2004:64). Perilaku insan televisi lebih mengedepankan hal hal yang diproduksi dengan waktu yan cepat, cepat laku dan cepat terjual meskipun tak ada kandungan 'gizi' untuk konsumennya.

Soimah adalah bentuk dari komodifikasi yang tujuan awalnya jelas untuk komersialisasi belaka, meskipun ada banyak keuntungan dari komodifikasi tersebut, seperti Soimah dianggap mempertahankan dan melestarikan budaya Jawa dimata masyarakat Indonesia sendiri dan mata dunia. Media dengan sengaja menempatkan posisi yang salah untuk soimah, yaitu dengan 'menjual' kekerasan lisan dalam bercanda dan gesture tubuh yang sama sekali tak mencerminkan sebagai seorang wanita pada umumnya bahkan jika menggunakan kebaya. Media kerap kali menampilkan sosok soimah sebagai sebuah dua kepribadian dalam satu jiwa yang bertolak belakang. Jiwa pertama, bisa dilihat dari packaging luar, kemasan atau tampilan ia berbalut kebaya yang anggun lengkap 

Peformance Multikultural Pada Sosok Soimah

dengan sanggul dan make up-nya sehingga persepsi masyarakat Soimah adalah cerminan budaya Jawa yang sesungguhnya telah mengakar sejak nenek moyang, Jiwa kedua adalah attitude yaitu dengan menunjukan sikapnya sebagai seorang wanita yang ber-gesture "urakan" / terkadang melakukan tingkah tingkah yang tak sepantasnya ia lakukan sebagai seorang wanita, terutama jika sedang menggunakan kebaya. Komunikasi lisan sebagai bahan komedi atau homor yang diucapkan acap kali penuh dengan kekerasan lisan, terlihat dari Intonasi, kata kata yang digunakan, hingga cara berekspresi.

Tidak salah jika sosok Soimah ditempatkan secara benar dalam media, biarkan publik mengenal Soimah sebagai seorang sinden dan pecinta budaya Jawa yang telah lama melintang dibidang seni dan memiliki segudang aktivitas untuk memperkenalkan buadaya Jawa di dunia serta mempertahankannya dinegara kita sendiri. Menjadi salah ketika unsur unsur budaya yang melekat di diri Soimah kemudian dijual, dikomodifikasikan dan ditambahi unsur unsur lainnya yang akhirnya akan membentuk persepsi yang buruk dimasyarakat akan unsur budaya yang melekat dalam dirinya.

Televisi memiliki pengaruh yang besar untuk memberikan sugesti khalayaknya. Televisi merupkan salah satu kekuatan terbesar dalam kemampuan menggiring opini publik. Menurut Effendi (2006) bahwa televisi sebagai fungsi media penyiaran memang bisa diandalkan, sebab televisi mempunyai daya tarik yang kuat karena memiliki unsur kata-kata, musik juga memiliki unsur visual berupa gambar hidup yang mampu menimbulkan kesan mendalam pada penonton. Ciri utama televisi adalah besarnya pengaturan, kontrol atau lisensi oleh penguasa yang awalnya datang dari kebutuhhan teknis, kemudian dari campuran anatara pilihan demokratis, kepentingan negara, kenyamanan ekonomi dan budaya lembaga yang bebas (McQuail,2011:38). Oleh karena itu televisi merupakan suatu kekuatan besar untuk menggiring masyarakat berfikir kearah yag diinginkan. Televisi sebagai media memiliki konten yang sangat beragam, saluran audiovisual, dianggap bersifat domestik, dekat, dan personal, Intensitas rendah dan pengalaman keterlibatan. Televisi sebagai lembaga memiliki teknologi dan organisasi yang rumit, Tunduk pada aturan dan kontrol sosial, berkarakter nasional dan interasional, dapat dilihat orang banyak (McQuail,2011:40).

Mosco (2009) memberikan tiga pintu gerbang untuk melihat konsep ekonomi politik media yaitu komodifikasi, spasialisasi dan strukturasi. Komodifikasi disini dapat kita definisikan sebagai proses mengubah nilai pada suatu produk yang tadinya hanya memiliki nilai guna kemudian menjadi nilai tukar (nilai jual) dimana nilai kebutuhan atas produk ini ditentukan lewat harga yang sudah 
dirancang oleh produsen (Mosco, 2009: 132). Dalam paper ini akan mengangkat tema komodifikasi yang dimaknai sebagai upaya mengubah apapun menjadi komoditas atau barang dagangan sebagai alat untuk mendapatkan keuntungan. Seperti : komodias isi media, jumlah audience dan iklan. Isi media adalah sebuah komditi yang dijual ke masyarakat. Komodifikasi adalah suatu proses mengubah barang dan jasa yang memiliki nilai guna untuk diubah menjadi komoditi yang memiliki nilai jual.

Media kini sebagai sektor yang menjanjikan dan dipandang sebagai ladang hijau yang memiliki potensi untuk digarap. Namun kebanyakan media swasta cenderung mengikuti trend yang sedang laku dipasaran. Sehingga mengakibatkan informasi yang diproduksi media kurang berkualitas. Banyak media yang berlomba lomba membuat siaran yang disukai masyarakat untuk mengejar rating, padahal para pelaku media juga harus memperhatikan fungsi sosial yaitu memberikan informasi yang berkualitas dan mendidik. Seperti memberikan infomasi untuk menambah pengetahuan masyarakat akan sesuatu hal yang positif, hiburan yang ringan namaun sehat, sinetron yang mendidik.

Realitanya, kini budaya budaya tidak sehat telah menjamur di televisi swasta, mulai terjadi pengikisan nilai nasionalisme, munculnya budaya westernisasi secara tak langsung berdampak bagi masa depan masyarakat kita. Hal ini dikarenakan kepentingan ekonomi pemilik modal yang kuat sehingga minim untuk membuat kualitas tayangan yang baik. Dan industri pertelevisian kita secara tidak langsung telah menerapkan unsur ekonomi yaitu dengan menekan biaya sekecil kecilnya untuk mendapatkan laba sebesar besarnya, artinya pelaku industri media lebih menekankan kuantitas dibandingkan kualitas. Perusakan budaya akibat program yang disajikan oleh media akan terus menggiring masyarakat menjadi kualitas diri yang buruk pula. Ada dua dimensi utama yang menjadikan komodifikasi penting dalam kajian komunikasi, yaitu : (1) Proses komunikasi dan teknologi berperan terhadap proses umum komodifikasi ekonomi secara keseluruhan dan (2) Proses komodifikasi yang terjadi di masyarakat menekan proses komunikasi dan institusi, sehingga perbaikan dan kontradiksi dalam proses komodifikasi sosial mempengaruhi komunikasi sebagai praktek sosial. Proses komodifikasi menjelaskan cara kapitalisme mencapai tujuan - tujuan dengan mengakumulasikan kapital atau merealisasikan nilai melalui transformasi nilai guna menjadi nilai tukar (Mosco,2009: 142). Dalam komunikasi, Mosco (2009:135-139), menyebutkan ada tiga bentuk komodifikasi yaitu: 


\section{Komodifikasi konten}

Para elite ekonomi menginginkan membuat komuditas dalam bentuk komunikasi, komodifikasi dalam komunikasi yang merubah bentuk pesan, mulai dari kode biner hingga sistem pemaknaan menjadi produk dagang. Proses menciptakan nilai tukar dalam konten komunikasi adalah keseluruhan aspek hubungan social dari komodifikasi termasuk dalam pekerja, ini adalah hubungan sosial yang terjadi antara pekerja, konsumen dan pemilik modal. Dalam masyarakat kapitalis media massa mengalihkan proses komoditi produksi seperti isi produk yang dikemas untuk mencerminkan kepentingan pemilik modal. Media juga sebagai entitas ekonomi memiliki peran langsung sebagai pencipta nilai surplus salah satunya melalui iklan dalam sektor produksi. Maka isi media yang disampaikan ke publik merupakan hasil kemampuan professional untuk memproduksi sebuah cerita dalan suatu sistem yang sarat makna dan menjadi layak untuk dilempar ke pasaran. (Mosco, 2009: 133-136)

Soimah adalah suatu bentuk penyajian komodifikasi isi, terlihat dari atribut budaya Jawa yang ia "perlakukan" tidak secara sakral, agung dan elegant, tidak sesuai dengan aslinya. Pergeseran tingkat kesakralan inilah yang menjadi inti sari atau isi pesan yang sesungguhnya dengan mengedepankan "kekinian" atau mengatasnamakan modernitas bahwa dengan sengaja berpesan bahwa sekarang sudah tak zaman budaya itu kolot, Jawa tak berhati "halus", lemot (lamban) dan masih banyak lagi pesan yang ingin disampaikan. Citra Jawa yang lekat dengan Soimah membuatnya kerap kali bertingkah berlebihan "lebay" alias sangat bertolak belakang dengan kebiasaan perempuan Jawa. Yang akan terjadi adalah diskriminasi dan minoritas perempuan Jawa yang kini dipandang tak mengerti estetika santun dalam berbicara.

Kebaya mengandung sarat makna perjuangan perempuan Indonesia. Kebaya menjadi simbol feminisme yang kini menjadi budaya nasional. Desainer terkenal Indonesia, Anne Avantie menyatakan rasa hormatnya pada kebaya yang dinilai merupakan simbol keanggunan, sekaligus busana perjuangan Indonesia. Dalam pertunjukan Fashion Week yang diselenggarakan di Jakarta baru baru ini, Anne berkolaborasi dengan Garin Nugroho menuturkan bahwa dengan menggunakan kebaya adalah rasa cinta negeri, rasa hormat pada bangsa sekaligus rasa cinta pada keindahan Nusantara. Begitu juga menurut Sammuel Muliah bahwa kebaya sebagai sebuah identitas nasional, memiliki kepribadian yang harus tetap utuh, namun style-nya boleh berubah agar tidak tergerus zaman, lewat tubuh berkebaya membawa hembusan angin segar dan napas pembaruan yang menjadikan wanita Indonesia lebih menarik lewat aneka siluet kebaya ("Kebaya, Simbol 
Perjuangan Kartini". Okezone.com, 23 April 2012).

Kebaya mencerminkan tingkah laku seorang perempuan. Kebaya adalah simbol Jawa yang seharusnya digunakan dengan cara yang benar dan logis. Sebuah simbolik yang patut untuk dibanggakan, oleh karena itu kebaya dianggap memiliki aura perjuangan kaum perempuan bagi siapapun yang menggunakannya. Kebaya hingga kini menemani perempuan dalam mengukir berbagai cerita hidup mereka. Namun pada Soimah simbol perjuangan ini memang disajikan melawan arus yang selama ini mengalir. Memberikan nuansa yang lebih cenderung negatif dengan bertingkah layaknya bukan seorang perempuan yang kita ketahui selama ini. Komodifikasi yang dilakukan media terhadap pesan pesan yang ingin disampaikan tersebut belum tentu berhasil dalam menyampaikan pesan pesan sesuai keinginan pihak media. Disini media terjerumus dalam tujuan antara ingin, mengeksistensikan budaya Jawa dengan tujuan untuk menggeser makna sesungguhnya budaya Jawa itu sendiri.

\section{Komodifikasi khalayak}

Dalam hal ini audiens dijadikan komoditas untuk dijual kepada para pengiklan, agar tayangan mereka penuh dengan para pihak yang ingin mengiklankan produk mereka. Pihak televisi berlomba mengumpulkan rating yang tinggi lewat kemasan acara yang menarik, agar nantinya rating tersebut dapat dijual kepada advertiser. Walaupun program yang dibuat mengesampingkan unsur moralitas dan edukasi sebagai mana fungsi media sesungguhnya. Audiens termasuk dalam audiens yang secara tak langsung atau tanpa disadari bekerja untuk meningkatkan keuntungan kapitalisme. Pemirsa bekerja dirumah dengan tetap menjalankan mereka sebagai sebuah keluarga kecil yang tak luput dari segala bentuk informasi dan hiburan media. Ketika pemirsa banyak yang menyukai acara tertentu baik karena sosok atau figur yang ada didalamnya, maka akan semakin banyak yang menonton, hal itu berdampak pada rating acara yang semakin tinggi sehingga permintaan iklan yang masuk semakin besar pula. Iklan adalah sumber penghidupan bagi tv swasta Indonesia, mereka berlomba lomba mencari pundi uang dengan memberikan beragam. Iklan adalah sebuah industri besar, salah satunya di Amerika, total pengeluaran iklan sendiri di Amerika Serikat (AS) mencapai US\$ 200 miliar di tahun 1998, dengan demikian pengeluara iklan untuk, wanita, pria dan anak yang hampir mencapai 270 juta jiwa di AS, pada tahun 1998 adalah lebih dari US\$ 700 (Shimp, 2003 : 356). Data ini bisa menjadi tolak ukur mengapa kini industri media kerap digarap serius dalam menghasilkan keuntungan dan mengkapitaliskan semua element didalamnya. 
Menurut Mosco (2009), rating merupakan unsur penting dalam komodifikasi isi dan khalayak di mana mereka menjadi komoditas utama industri media. Rating adalah bagian dari immanent commodification atau hasil dari komodifikasi yang sudah ada (komodifikasi isi, khalayak dan pekerja). Rating merupakan immanent commodities karena dibentuk sebagai komoditas dalam proses yang memberi kontribusi teehadap produksi komoditas.

\section{Komodifikasi pekerja}

Bahwa perusahaan media massa pada kenyataannya tidak berbeda dengan pabrik- pabrik. Para pekerja tidak saja memproduksi content dan mendapatkan penghargaan terhadap upaya menyenangkan khalayak dalam konten tersebut. Melainkan juga menciptakan khalayak sebagai pekerja yang terlibat dalam mendistribusikan konten sebuah komoditas (Mosco, 2009). Hal ini terlihat dimana secara tak disadari khalayak mentransformasikan dirinya tak hanya sekedar menjadi konsumen melainkan produsen. Menurut Braverman, Labor (pekerja) terbentuk dari kesatuan konsep atau kekuatan untuk membayangkan, imajinasi dan desain, dan eksekusi/ pelaksanaan, atau kekuatan untuk mengutarakannya. Labor (Pekerja) merupakan penggerak kegiatan produksi dan juga distribusi. Para pekerja dimanfaatkan pikiran dan tenaganya semaksimal mungkin dengan cara mengkonstruksikan pikiran mereka tentang hal - hal yang menyenangkan saat bekerja di perusahaan media massa walaupun dengan gaji yang tidak seharusnya. Dalam proses komodifikasi, capital bertindak untuk memisahkan konsep dari eksekusi, ketrampilan dari kemampuan untuk menyelesaikan tugas. Perhatian akan tertuju pada kekuasaaan class tertentu yang merupakan bagian dari capital.

Budaya Jawa identik dengan nilai kesakralan yang dijaga secara turun temurun, namun kehadiran Soimah membuat nilai sakral tersebut luntur, esensi utama identitas Jawa sebagai budaya yang sopan luntur dengan perlahan, publik tidak lagi menafsirkan kebudayaan Jawa sebagaimana nilai nilai terdahulu, namun lebih menginterpretasikan pergeseran citra dan cara memandang, memaknai budaya tersebut. Tanpa disadari pemirsa menyukai sosok Soimah yang ditampilkan ditelevisi, sehingga pasar media terus saja berjalan lihai untuk mengumpulkan pundi pundi uang walaupun dengan cara diskriminasi kesukuan.

\section{Penutup}

Fungsi televisi yang lebih mementingkan keuntungan atau profit akhirnya mengesampingkan kewajiban mereka sebagai industri media yang sesungguhnya. Tidak hanya Soimah yang menjadi 'korban' komodifikasi, masih banyak lagi. Terutama masalah 
ambiguitas pesan, dimana unsur budaya yang awalnya untuk memperkenalkan masyarakat akan kebudayaan Jawa yang ternyata masih dapat eksis tetapi akhirnya bergeser dengan menampilkan unsurunsur humoris yang tak selayaknya disejajarkan dengan kebudayaan Jawa untuk dijadikan produk yang menghasilkan banyak keuntungan semata. Insan televisi terjebak dalam penggunaan kebudayaan untuk dijadikan produk yang tak semestinya. Seharusnya sosok Soimah adalah sosok unik yang harus dimanfaatkan secara benar dan tepat, kerena melaluinya kita bisa melihat peluang untuk dapat membantu pemerintah melestarikan budaya tanah air yang malah semakin pudar di negeri sendiri. Untuk itu, unsur humoris, gesture tak layak dan tak pantas disejajarkan atau disatupadukan dengan unsur budaya seperti kebaya yang melekat di tubuh Soimah berisiko dapat meleburkan nilai kesakralan atribut Jawa sebagai sesuatu yang tidak berarti. Hal tersebut mungkin akan memunculkan ambiguitas atau proses pemaknaan pesan yang diterima masyarakat tentang sosok Soimah yang disajikan oleh media massa bisa menggeser citra masyarakat Jawa serta kebudayaannya. 


\section{DAFTAR PUSTAKA}

\section{Buku:}

Effendi, Onong Uchjana. 2006. Dimensidimensi Komunikasi. Bandung : Remaja Rosdakarya.

McQuail, Denis. 2011. Teori Komunikasi Massa McQuail. Edisi 6.Buku 1.Jakarta : Salemba Humanika.

Habermas,Jurgen. 1991. The Structural Transformation of the Public Sphere: An Inquiry into a Category of Bourgeois Society (Studies in Contemporary German Social Thought)......MIT Press

Hall, Stuart. 1997. Representation, Cultural Representations and Signifying Practices.London: Sage Publication.

Mosco, Vincent. 2009. The Political Economy of Communication. 2nd. London: Sage Publications.

Kroeber, A. L. , Clyde Kluckhohn, Wayne Untereiner, Alfred G. Meyer Culture. 1952. A Critical Review of Concepts and Definitions. Vintage Books: New York. Publication

Shimp, Terence. 2003. Periklanan Promosi. Jakarta : Erlangga

Sudibyo, Agus. 2004. Ekonomi Politik Media Penyiaran. Yogyakarta : LKIS

\section{Internet}

"Mamiek Prakoso: Pelawak Sebagai Penghibur bukan Penghancur" http://lifestyle.kompasiana.com/cat atan/2012/06/30/mamiek-prakosopelawak-sebagai-penghibur-bukanpenghancur/2012/6/30, diakses 1 September 2013

"Kebaya, Simbol Perjuangan Kartini". Okezone.com, 23 April 2012. http://lifestyle.okezone.com/read/2 012/04/23/29/6164.35/kebayasimbol-perjuangan-kartini , diakses 15 September 2013

“Televisi Pengaruhi Wajah Media, Meski Pemirsa Kerap Tak Tahu Realitas Asli Peristiwa”. Republika.co.id, 27 November 2011, http://www.republika.co.id/berita/ nasional/umum/11/11/27/lva7ldtelevisi -pengaruhi-wajah-mediameski-pemirsa-kerap-tak-tahurealitas-asli-peristiwa, diakses pada 3 Oktober 2013 
Jurnal komunikasi, Volume 8, Nomor 1, Oktober 2013 